Article

\title{
Evaluation of the Accuracy of Different PV Estimation Models and the Effect of Dust Cleaning: Case Study a 103 MW PV Plant in Jordan
}

\author{
Loiy Al-Ghussain $1, * \mathbb{D}$, Moath Abu Subaih ${ }^{2}$ and Andres Annuk ${ }^{3}$ \\ 1 Mechanical Engineering Department, University of Kentucky, Lexington, KY 40506, USA \\ 2 Planning Operation Section, SAMRA Electric Power Company (SEPCO), Amman 11821, Jordan; \\ masbaih@sepco.com.jo \\ 3 Energy Application Engineering, Estonian University of Life Sciences, 51006 Tartu, Estonia; \\ andres.annuk@emu.ee \\ * Correspondence: Loiy.al-ghussain@uky.edu
}

Citation: Al-Ghussain, L.; Subaih, M.A.; Annuk, A. Evaluation of the Accuracy of Different PV Estimation Models and the Effect of Dust Cleaning: Case Study a 103 MW PV Plant in Jordan. Sustainability 2022, 14, 982. https://doi.org/10.3390/ su14020982

Academic Editor: Tamer Khatib

Received: 12 December 2021

Accepted: 11 January 2022

Published: 16 January 2022

Publisher's Note: MDPI stays neutral with regard to jurisdictional claims in published maps and institutional affiliations.

Copyright: (c) 2022 by the authors Licensee MDPI, Basel, Switzerland. This article is an open access article distributed under the terms and conditions of the Creative Commons Attribution (CC BY) license (https:// creativecommons.org/licenses/by/ $4.0 /)$.

\begin{abstract}
The estimation of PV production has been widely investigated previously, where many empirical models have been proposed to account for wind and soiling effects for specific locations. However, the performance of these models varies among the investigated sites. Hence, it is vital to assess and evaluate the performance of these models and benchmark them against the common PV estimation model that accounts only for the ambient temperature. Therefore, this study aims to evaluate the accuracy and performance of four empirical wind models considering the soiling effect, and compare them to the standard model for a 103 MW PV plant in Jordan. Moreover, the study investigates the effect of cleaning frequency on the annual energy production and the plant's levelized cost of electricity $(L C O E)$. The results indicate almost identical performance for the adopted models when comparing the actual energy production with $\mathrm{R}^{2}$ and RMSE (root mean square error) ranges of $0.93-0.98$ and $0.93-1.56 \mathrm{MWh}$ for both sub-plants, with a slight superiority of the models that incorporate wind effect. Finally, it is recommended in this study to clean the PV panels every two weeks instead of every three months, which would increase annual energy production by $4 \%$, and decrease the $L C O E$ by $5 \%$ of the two PV sub-plants.
\end{abstract}

Keywords: PV energy estimation models; large-scale PV plants; wind effect; soiling effect; cleaning frequency

\section{Introduction}

The spread of the Corona virus (COVID-19) and the lockdown around the world in 2020 caused a drop in fossil fuel consumption along with a drop in the prices, which contributed to the mitigation of greenhouse gases in that year [1,2]. However, the dependency on fossil fuels is still significant, with a tremendous amount of greenhouse emissions escalating the global warming consequences. For instance, huge forest fires have increased due to global warming [3], in different countries around the world such as Algeria, Turkey, and Greece. This urgent global problem has crossed regional borders, and needs coordination and cooperation from all countries to solve it, as agreed upon the Paris Agreement in 2016 [4]. Accordingly, many countries have increased their energy sector share of clean and renewable energy resources such as solar, wind, hydropower, geothermal, tidal, and biomass [5].

The Hashemite Kingdom of Jordan is one of the countries in the Middle East with significant concerns regarding its energy security, and fewer concerns about global warming. These concerns were raised due to the limited traditional energy resources [6], with almost total dependency on imported energy, where $97 \%$ of Jordan's energy demand is imported [7]. This dependency causes significant pressure on the economy since a vast 
portion of the annual Jordanian budget is spent on importing this demand, which causes an outflow of foreign currency. On the other hand, similar to many countries in the region, Jordan is rich with renewable energy resources, especially solar energy in almost all of the country, and wind energy in some areas in the north [6,8]. Therefore, Jordan has recently started to increase the share of renewable energy sources in its energy market. For instance, between 2017 and 2020 the installed solar and wind capacities were raised almost threefold, as reported in [9], where the installed solar capacities increased from $591 \mathrm{GWh}$ in 2017 to $1645 \mathrm{GWh}$ in 2020. At the same time, the installed wind capacities increased from $447 \mathrm{GWh}$ to 1378 GWh between 2017 and 2020 [9]. This significant increase is related to the change in energy policy in Jordan, as well as the drops in the prices of renewable energy systems, especially solar systems [5]. The Jordanian movement towards increasing the share of renewables is projected to surge, as highlighted by the 2020-2030 strategic energy plan, where there is an intention to increase the share of renewable energy from $11 \%$ in 2020 to $48 \%$ in 2030 [10].

As aforementioned, Jordan is located in an area with high solar potential, where the investments in solar energy projects have proven to be technically and economically feasible, especially in the southern part (Ma'an, Aqaba, Tafilah, and Karak) [6,11,12]. For instance, these regions have an average sunshine duration of about 300 days per year [13], and annual daily average solar radiation on a horizontal surface of $5-7 \mathrm{kWh} / \mathrm{m}^{2}[13,14]$, which is one of the highest values in the world. Hence, most renewable energy investments in Jordan are in solar energy systems. It is reported that the solar systems have the largest contribution of almost 9\% of the renewable energy share in Jordan [9].

The energy production of PV plants is highly affected by the ambient conditions (other than the solar radiation [15]), especially the ambient temperature [16], which has been incorporated in the standard energy estimation models of PV plants [17]. Other studies have highlighted the effect of wind speed [18-22], relative humidity [23,24], and dust/soil accumulation [24,25] on PV production. For instance, excluding wind data from PV estimation models could underestimate the PV production by 3.5\%, as reported in [26]. Other studies such as [27] reported the necessity to include the wind speed and direction to better estimate the PV production. Likewise, excluding the dust/soiling effect results in overestimating the energy production [28,29]. For example, Zaihidee et al., [30] found that dust accumulation of $20 \mathrm{~g} / \mathrm{m}^{2}$ on a PV panel reduces its efficiency by $15-35 \%$. Moreover, Ullah et al., [31] reported a 10-40\% decrease in the monthly power production due to soil accumulation in Pakistan. Other studies such as [5] reported that in Oman the losses in the monthly energy production could reach $10.8 \%$ if proper cleaning is not maintained. Furthermore, studies in Jordan, specifically in Ma'an [25], showed the importance of a monthly cleaning process to minimize power production losses to $2.2 \%$. However, other studies showed that the most feasible cleaning period is 15 days for PV plants in Tafilah, Jordan [16,32].

The ability to estimate the PV production accurately by incorporating these ambient conditions is vital to policymakers and investors. Excluding these factors from the energy estimation models could over- or underestimate the energy production, and affect the system's technical and economic feasibility. Therefore, it is crucial to incorporate the soiling and wind effects in estimating the energy production, especially from large-scale PV plants, where minor inaccuracies could propagate and result in estimation errors up to the plant size. A few studies have investigated the performance of PV energy production models, and benchmarked them against the actual production of fixed PV plants with capacities up to $20 \mathrm{MW}$ [33-38]. However, to the best of the authors' knowledge the literature lacks studies that:

- $\quad$ Evaluated the performance of different energy estimation models of large-scale (larger than $20 \mathrm{MW}$ ) fixed and tracked PV power plants.

- Investigated the effect of cleaning cycle frequency on the energy production of largescale fixed and tracked PV plants. 
- Estimated the best cleaning frequency for large-scale fixed and tracked PV plants in arid and dusty climates.

Therefore, this study aims to:

- Investigate the performance of five energy estimation models, and benchmark them against the actual energy production of large-scale fixed and single-axis tracked PV plants in Jordan with a total capacity of 103 MW.

- Investigate the effect of cleaning cycle frequency on the annual energy production and the LCOE of the plant.

- Find the best cleaning frequency that maximizes the annual energy production of the two plants, and compare it with the current cleaning frequency.

\section{Theory and Methodology}

\subsection{PV Plant Overview}

The PV power plant investigated in this study is located in Al-Rashadyah, south of Jordan $\left(29.743976^{\circ} \mathrm{N} 35.360954^{\circ} \mathrm{E}\right)$. The plant's location is characterized by a hot, arid, and dusty climate due to its desert-like nature, with average daily global solar radiation of $6.15 \mathrm{kWh} / \mathrm{m}^{2}$, ambient temperature of $20^{\circ} \mathrm{C}$, and wind speed of $2.26 \mathrm{~m} / \mathrm{s}$. The first three subplots in Figure 1 show the measured average hourly ambient conditions at the PV plant location. The power plant has several weather stations that measure the ambient conditions and the hourly energy production - shown in Figure 1-using different instrumentations as shown in Table 1. The studied PV plant is considered one of the largest solar plants in Jordan (2nd in ranking), with a total capacity of $103 \mathrm{MW}$. The plant consists of two subplants as indicated in Table 2. The technical specifications of the PV modules are essential for accurate estimation of their energy production. PV modules used in the Al-Rashadyah plant are manufactured by Jinko Solar Company, where the specifications are shown in Table 3. Due to the dusty nature of the PV plant location, regular cleaning and maintenance are maintained. The normal cleaning period adopted in this plant is three months, where machine-based dry cleaning is used in this plant.
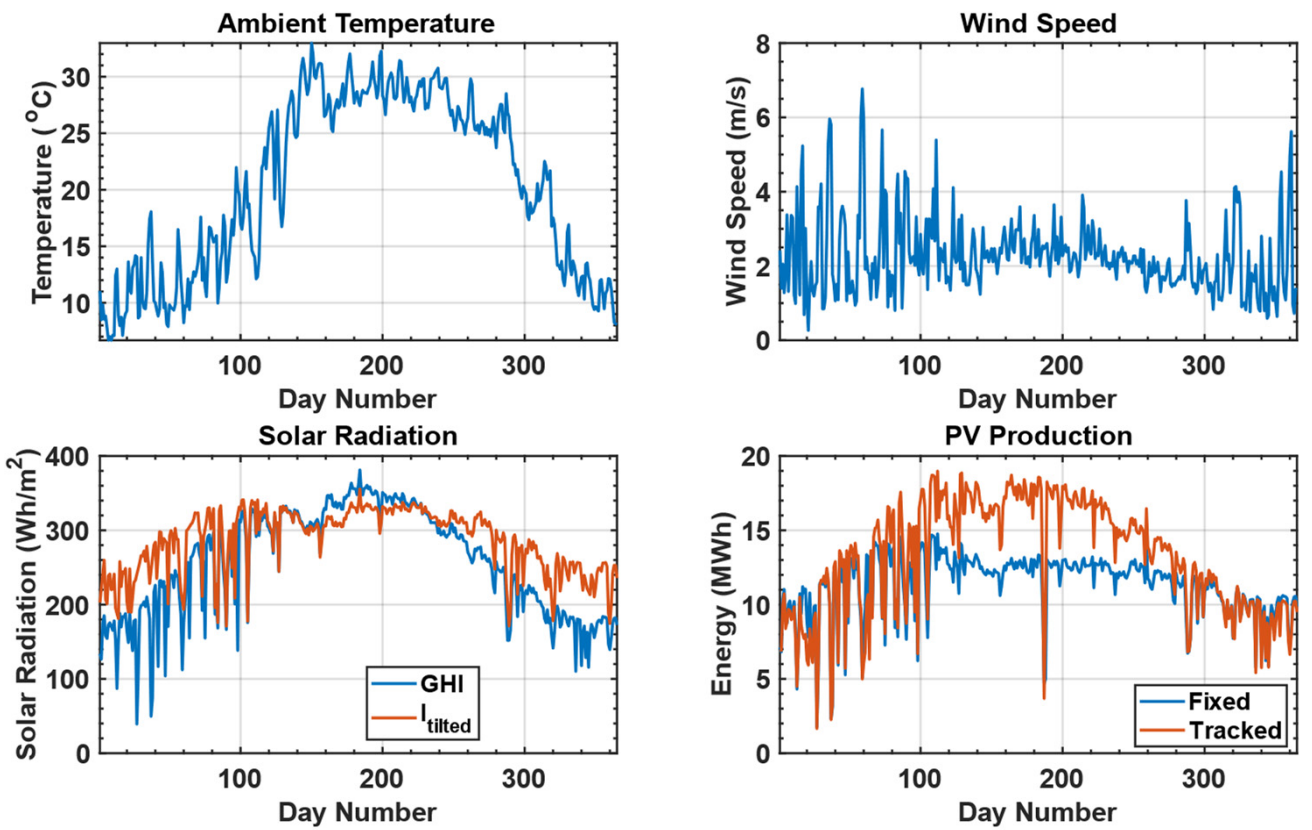

Figure 1. Overview of the average hourly ambient conditions at the PV plants and the actual average hourly PV production. 
Table 1. Overview of the measurements acquired at the PV plant.

\begin{tabular}{|c|c|c|c|c|}
\hline Measurement & Accuracy & Frequency & $\begin{array}{l}\text { Measurement } \\
\text { Device }\end{array}$ & Model \\
\hline Ambient temperature & $\pm 0.1^{\circ} \mathrm{C}$ & & STH-S331 & Pt100 RTD \\
\hline Humidity & $\pm 0.8 \% \mathrm{RH}$ & & STH-S331 & Hygromer IN1 \\
\hline \multirow[t]{2}{*}{ Wind speed and direction } & $\begin{array}{l}\text { Wind speed: } \\
\pm 0.5 \mathrm{~m} / \mathrm{s}\end{array}$ & & & \\
\hline & $\begin{array}{l}\text { Wind direction: } \\
\pm 50\end{array}$ & $5 \mathrm{~min}$ & $\begin{array}{l}\text { Wind Sentry } \\
\text { Anemomter \& } \\
\text { Vane }\end{array}$ & 03002 \\
\hline \multicolumn{5}{|l|}{ GHI: } \\
\hline Radiation on tilted surface & $1 \mathrm{~W} / \mathrm{m}^{2}$ & & Pyranometer & GEO-SR20 \\
\hline PV production & - & $1 \mathrm{hr}$ & - & - \\
\hline
\end{tabular}

Table 2. Design parameters of the PV plant.

\begin{tabular}{lll}
\hline Design Parameters & Characteristics & \\
\hline Installation Type & Fixed Panels & Single-Axis Tracking Panels \\
\hline Capacity & $51.7 \mathrm{MW}$ & $51.7 \mathrm{MW}$ \\
\hline Module type & Poly-crystalline & \\
\hline Module model & JKM315PP-72 & JKM315PP-72-V \\
\hline Tilt angle & $22^{\circ}$ & - \\
\hline Surface azimuth angle & $0^{\circ}$ (South) & $0^{\circ}$ (South) \\
\hline Rotation limitation & - & $-45^{\circ}$ to $45^{\circ}$ \\
\hline Inverters & INGETEAM $1108 \mathrm{KW} \mathrm{AC}$ & \\
\hline Transformers & INGETEAM $3150 \mathrm{KVA}, 50 \mathrm{~Hz}, 0.4 \mathrm{KV} / 33 \mathrm{KV}$ \\
\hline
\end{tabular}

Table 3. Technical specifications of the PV modules installed at the plant.

\begin{tabular}{ll}
\hline Parameter & Value \\
\hline Maximum power & $315 \mathrm{~W} p$ \\
Maximum power voltage & $37.2 \mathrm{~V}$ \\
Maximum power current & $8.48 \mathrm{~A}$ \\
Open-circuit voltage & $46.2 \mathrm{~V}$ \\
Short-circuit current & $9.01 \mathrm{~A}$ \\
Operating Temperature & $-40{ }^{\circ} \mathrm{C}+85^{\circ} \mathrm{C}$ \\
Module Efficiency & $16.23 \%$ \\
Temperature Coefficient & $-0.4 \% /{ }^{\circ} \mathrm{C}$ \\
NOCT & $45^{\circ} \mathrm{C}$ \\
Wind speed at NOCT & $1 \mathrm{~m} / \mathrm{s}$ \\
STC temperature & $25{ }^{\circ} \mathrm{C}$ \\
STC Radiation & $1000 \mathrm{~W} / \mathrm{m}^{2}$ \\
PV lifespan & 25 years \\
\hline
\end{tabular}

As aforementioned, the plant consists of two parts: a fixed system with PV panels facing the south and a $22^{\circ}$ tilt angle, and a single-axis tracking system (around the horizontal axis). Each sub-plant consists of 19 PV stations, where each station has three inverters; each inverter is connected to six combiners. The combiner consists of 24 strings; each string has 20 PV panels connected in series. The total number of components in the PV plant is shown in Table 4. Figure 2 shows a general schematic diagram of the PV power plant, whereas Figure 3 shows the schematic diagram of each PV station. 
Table 4. PV power plant components details.

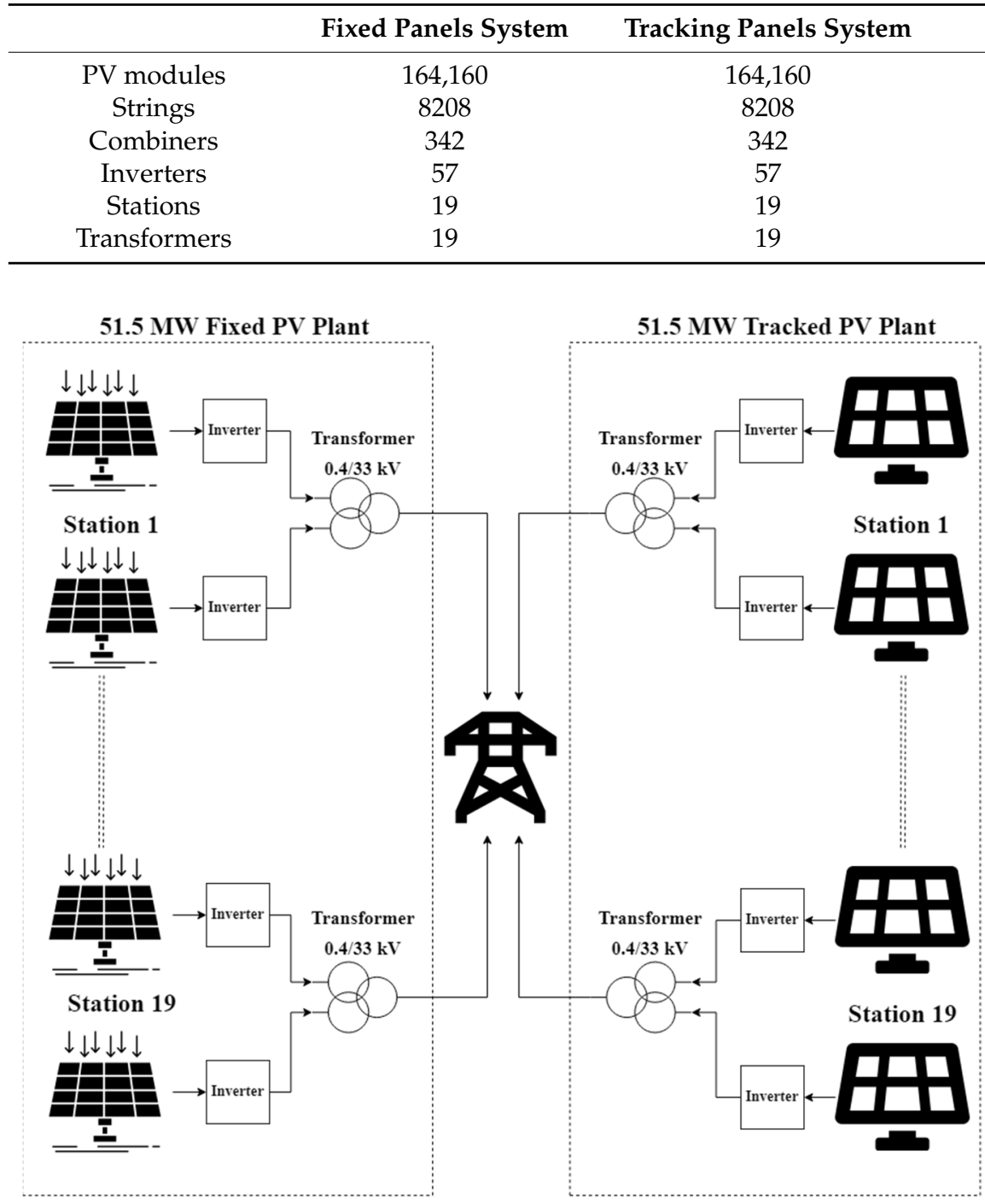

Figure 2. General schematic diagram of the investigated 103 MW PV plant.

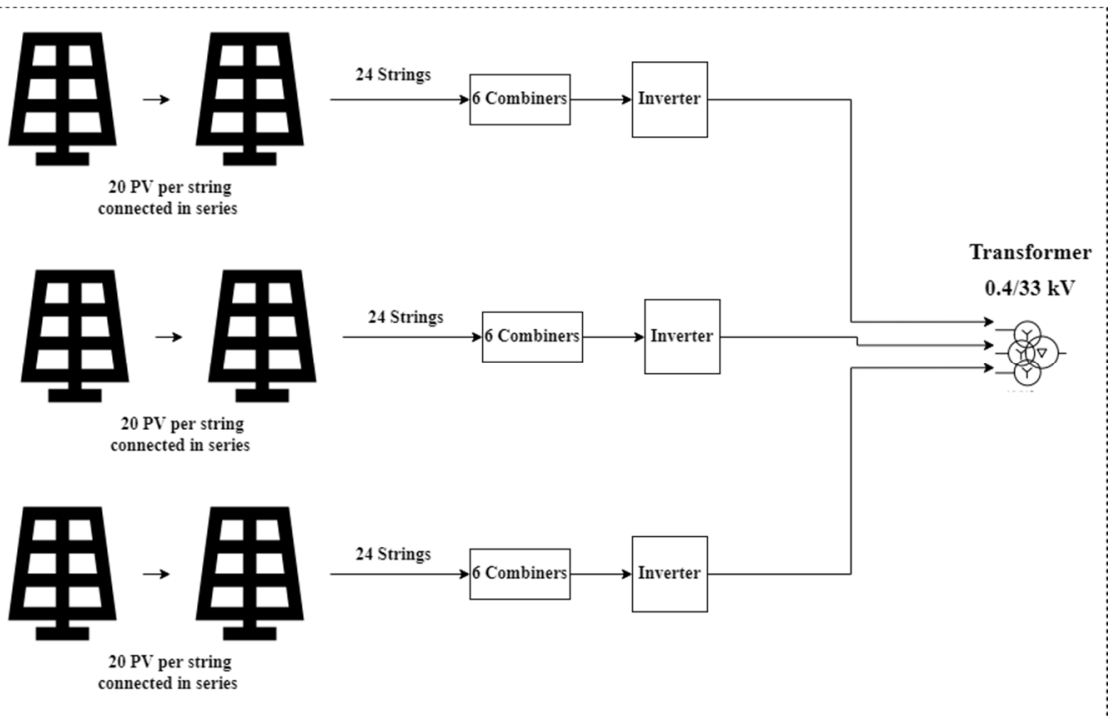

Figure 3. Schematic diagram of each PV station. 


\subsection{Modeling PV Production}

The energy production from PV plants is directly correlated with the site's solar resources, but it is also affected by the ambient conditions, especially the ambient temperature. The ambient temperature increases the PV cell temperature and decreases the energy production by a specific rate, depending on the cell's specifications. Many researches (e.g., Schwingshackl et al., [18]) highlighted the need to include the effect of wind speeds in estimating the PV cell temperature, where wind speeds could contribute to cooling the PV panels and increasing energy production. Several models have been proposed to account for the wind effect, as reported by [18]. In this study, the performance of five models (standard model and four wind models) in the PV energy estimation was benchmarked against the actual energy produced from the PV plant. These models are shown in Table 5, and were adopted from [18]. Root mean square error (RMSE) and coefficient of determination $\left(\mathrm{R}^{2}\right)$ were used as the judging parameters. It should be noted that the local wind speed as suggested by [39] was used in these models, which can be estimated with the availability of wind speed measurements at ground level (10 m) using Equation (1).

$$
v_{w}=0.68 \times U-0.5
$$

Table 5. The empirical cell temperature models used in this study [18].

\begin{tabular}{|c|c|c|}
\hline Model & Formula & Ref. \\
\hline Standard & $T_{P V}=T_{a}+\left(\mathrm{NOCT}-\mathrm{T}_{\mathrm{stc}}\right) \times \frac{I_{t, e f}}{\mathrm{I}_{\mathrm{ref}}}$ & [17] \\
\hline 1 & $\begin{array}{c}T_{P V}=\frac{U_{P V} \times T_{a}+I_{t, e f} \times\left(0.81-\eta_{P V, r e f} \times\left(1-\beta_{r e f} \times T_{s t c}\right)\right)}{U_{P V}+\beta_{r e f} \times \eta_{P V, r e f} \times I_{t, e f}} \\
\text { with } \\
U_{P V}=26.6+2.3 \times v_{w}\end{array}$ & [22] \\
\hline 2 & $\begin{array}{c}T_{P V}=T_{a}+\left(\mathrm{NOCT}-\mathrm{T}_{\mathrm{stc}}\right) \times \frac{I_{t, e f}}{I_{\text {ref }}} \times \frac{h_{w, \text { NOCT }}}{h_{w}} \times\left(1-\frac{\eta_{P V, \text { ref }}}{0.9}\right) \times\left(1-\beta_{r e f} \times T_{s t c}\right) \\
\text { with } \\
h_{w}=5.7+2.8 \times v_{w} \\
h_{w, N O C T}=5.7+2.8 \times v_{W, N O C T}\end{array}$ & [19] \\
\hline 3 & $\begin{array}{c}T_{P V}=T_{a}+\frac{I_{t, e f}}{\alpha_{1} \times v_{\tau w}+\alpha_{0}} \\
\text { with } a_{1}=6.28 \mathrm{~W} \mathrm{~s} /{ }^{\circ} \mathrm{C} \mathrm{m}^{3} \text { and } a_{0}=30.02 \mathrm{~W} /{ }^{\circ} \mathrm{C} \mathrm{m}^{2} \text { for polycrystalline PV modules [21]. }\end{array}$ & [21] \\
\hline 4 & $T_{P V}=T_{a}+I_{t, e f} \times \exp \left(-3.473-0.0594 \times v_{w}\right)$ & [20] \\
\hline
\end{tabular}

In addition to the ambient temperature and wind speeds, dust (or soil) significantly affects the energy produced by PV modules. The accumulation of dust on the PV module causes shading, and scatters the radiation, especially in dry regions such as Jordan $[16,40]$. One of the means used to estimate the drop in the energy generation is the soiling ratio (SR), as demonstrated in [41], where experimental studies such as $[25,40,41]$ have found the average soiling ratio for different regions in Jordan. The PV plant location analyzed in this study is close to the location (Ma'an) investigated in [25], with similar ambient conditions. Hence, the average soiling ratio was adopted from that study. It is assumed in this study that the soiling ratio is constant throughout the year, and based on [25], the hourly soiling ratio is set to be $0.0065 \%$.

It should be noted that this soiling ratio is the accumulative quantity unless the PV panel is cleaned, in which case the accumulation of SR restarts from the cleaning time. With the SR, the effective solar radiation incident on the PV module can be estimated using Equation (2), whereas the estimation of the hourly energy produced by the PV can be calculated using Equation (3). It should be noted that the reference cleaning frequency used in this study for evaluating all the models in Table 5 is 12 weeks ( 3 months). Moreover, the best cleaning frequency is assumed to be in the order of weeks with a time step of one week. 
Figure 4 shows the procedure adopted in this study to estimate the energy production from the PV power plant.

$$
\begin{gathered}
I_{t, e f}=I_{t n} \times\left(1-\sum_{i=t_{t c}}^{n} S R_{i}\right) \\
E_{\text {estimated }}=\left[\eta_{P V, r e f} \times \beta_{\text {ref }} \times\left(T_{P V}-T_{s t c}\right)\right] \times I_{t, e f} \times A_{P V} \times N_{P V} \times P_{r}
\end{gathered}
$$

where $P_{r}$ is assumed to be 0.85 , which accounts for wiring, inverter, and shading losses [42].

Estimate the effective radiation incident on the PV module

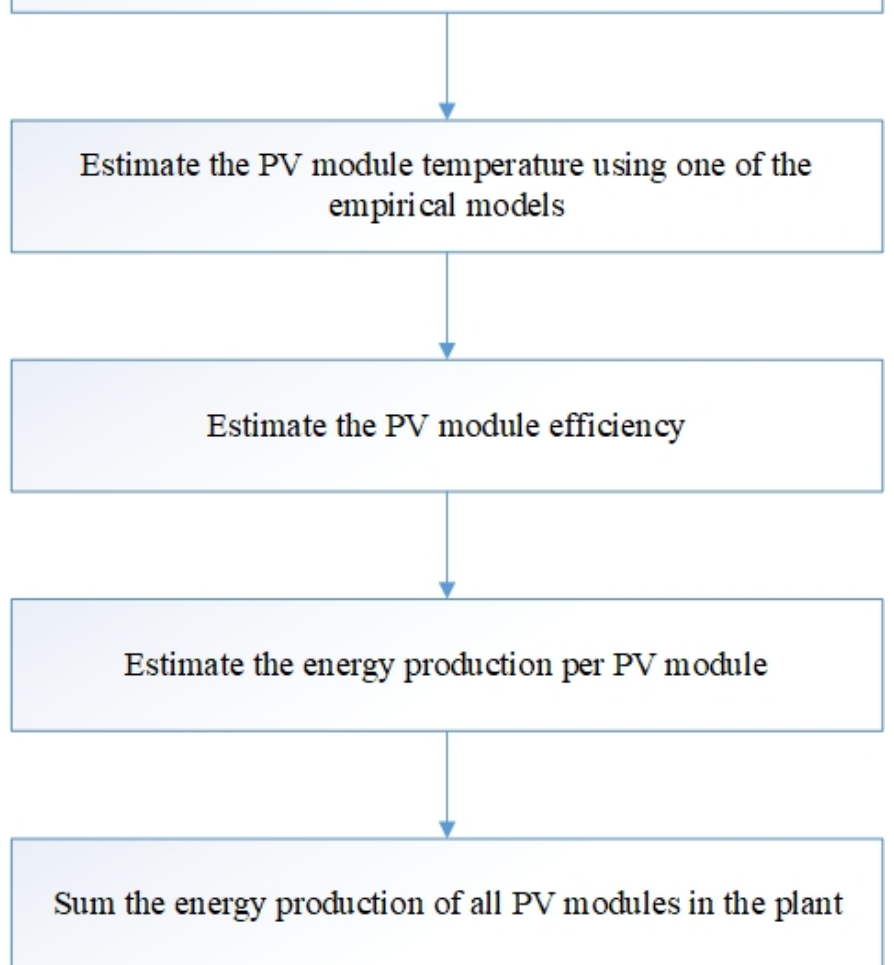

Figure 4. The procedure adopted to estimate the energy production from the PV plant.

\subsection{Plant Economics}

It is vital to assess this effect, and to investigate the benefits of more frequent cleaning of the PV modules considering the additional cleaning cost. The levelized cost of electricity ( $L C O E)$ is one of the most common parameters used to assess the economic feasibility of energy systems, which was used in $[1,43]$. The $L C O E$ is sensitive to any additional costssuch as the cleaning cost-and also to the variation in the annual energy production. Hence, it represents a suitable parameter for assessing the viability of more frequent cleaning of the PV modules. The LCOE can be estimated using Equation (4) with the economic parameters listed in Table 6.

$$
L C O E=\frac{C_{P V}+\sum_{y=1}^{L_{f}} \frac{M_{t}+C_{L}}{(1+d)^{y}}}{\sum_{y=1}^{L_{f}} \frac{E_{\text {estimated }}}{(1+d)^{y}}}
$$

where

$$
C l_{c}=R_{c l} \times A_{P V} \times N_{P V} \times\left(N_{\text {weeks }} / f_{c l}\right)
$$


Table 6. The economic parameters used in this study.

\begin{tabular}{|c|c|c|c|c|}
\hline Parameter & Unit & Plant Type & Value & Ref. \\
\hline \multirow{2}{*}{ PV capital cost } & \multirow{2}{*}{ (USD/kWp) } & Fixed & 1280 & \multirow{2}{*}[44]{} \\
\hline & & Tracked & 1350 & \\
\hline \multirow{2}{*}{ Annual maintenance cost } & \multirow{2}{*}{ (USD/kWp) } & Fixed & 24 & \multirow{2}{*}[17,45]{} \\
\hline & & Tracked & 24 & \\
\hline \multirow{2}{*}{ Machine-based cleaning cost } & \multirow{2}{*}{$\left(\mathrm{USD} / \mathrm{m}^{2} /\right.$ cycle $)$} & Fixed & 0.005 & \multirow{2}{*}{ [32] } \\
\hline & & Tracked & 0.005 & \\
\hline \multirow{2}{*}{ Annual discount rate } & \multirow{2}{*}{$(\%)$} & Fixed & 5 & \multirow{2}{*}{ [46] } \\
\hline & & Tracked & 5 & \\
\hline
\end{tabular}

\section{Results and Discussion}

\subsection{PV Production Models}

As aforementioned, the ability to accurately estimate the energy production from PV plants is vital to policymakers, PV plant owners, and any potential investor to assess the techno-economic feasibility of the PV plants. The literature is rich with models used to estimate this energy production, where most of these models have decent accuracy. The most common model is the standard one that only considers the effect of ambient temperature. The performance of this model in estimating the energy production of fixed and tracked PV plants is outstanding, as shown in Figure 5, with $R^{2}$ of 0.9849 and 0.9335 for the fixed and tracked sub-plants, respectively. Including the wind, the effect is expected to enhance the PV models' estimation accuracy, which would vary among the empirical models. It can be depicted from Figures 6 and 7 that all the models that incorporated the wind effect slightly outperformed the standard model in terms of $\mathrm{R}^{2}$.
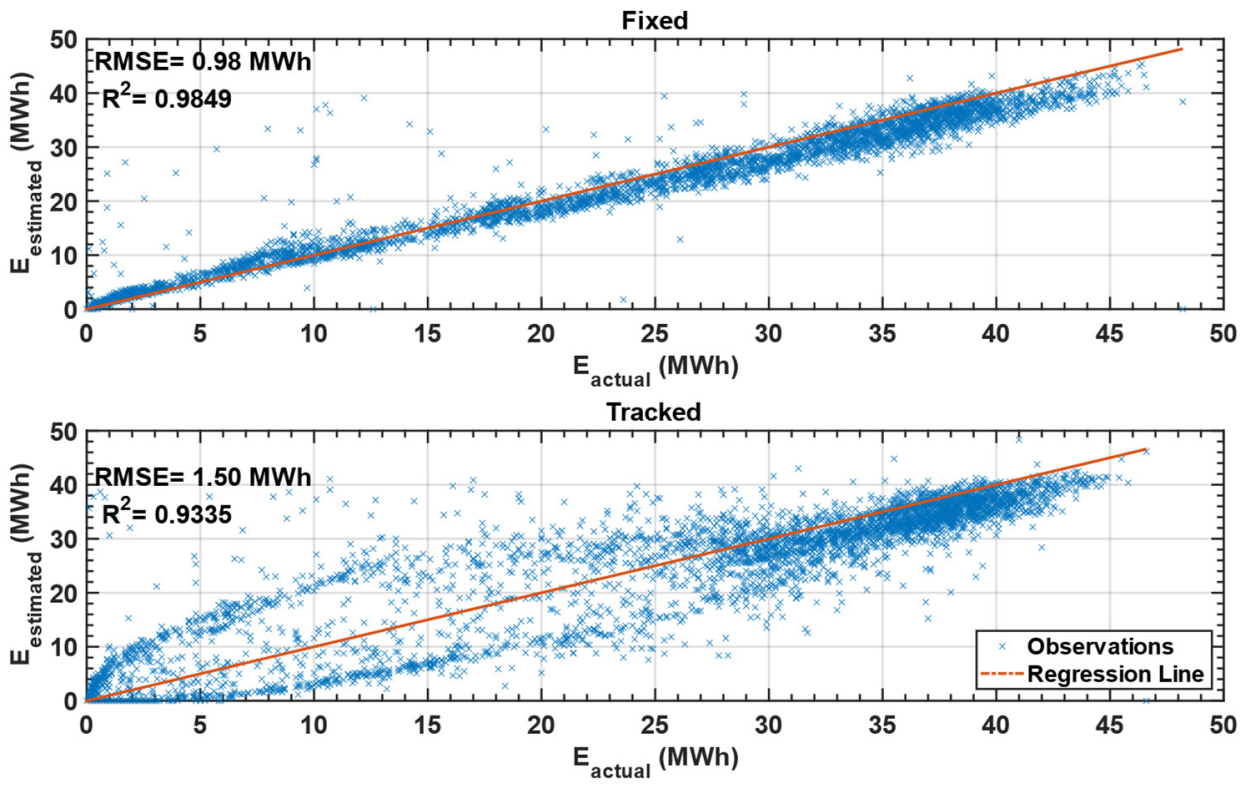

Figure 5. The goodness of fit of the standard energy estimation model.

In contrast, model 2 outperformed the standard models in terms of RMSE for both sub-plants. The adopted models in this study have very similar performance in estimating the energy production with $\mathrm{R}^{2}$ of 0.985 and RMSE between $0.93-1.08 \mathrm{MWh}$ for the fixed PV plant, where model 2 suggested by [19] slightly outperformed the rest of the models in terms of $\mathrm{R}^{2}$ and RMSE, as shown in Figure 6. While the performance of these models in the case of the single-axis tracked PV plant decreases in terms of $\mathrm{R}^{2}$ to 0.9343 with the superiority of model 2, as shown in Figure 7. The main reason for this drop in the 
performance can be related to estimating the local wind speeds on the PV modules. The used empirical models were developed for fixed PV modules, and did not incorporate the variation in PV tilt angle. The movement of the PV modules affects the cooling caused by wind speeds (more cooling is predicted when the wind is parallel to the PV module), especially with the variation in the wind direction. The unavailability of the wind direction data from the measuring station is one of the barriers that hinged the investigation of this effect in this study.
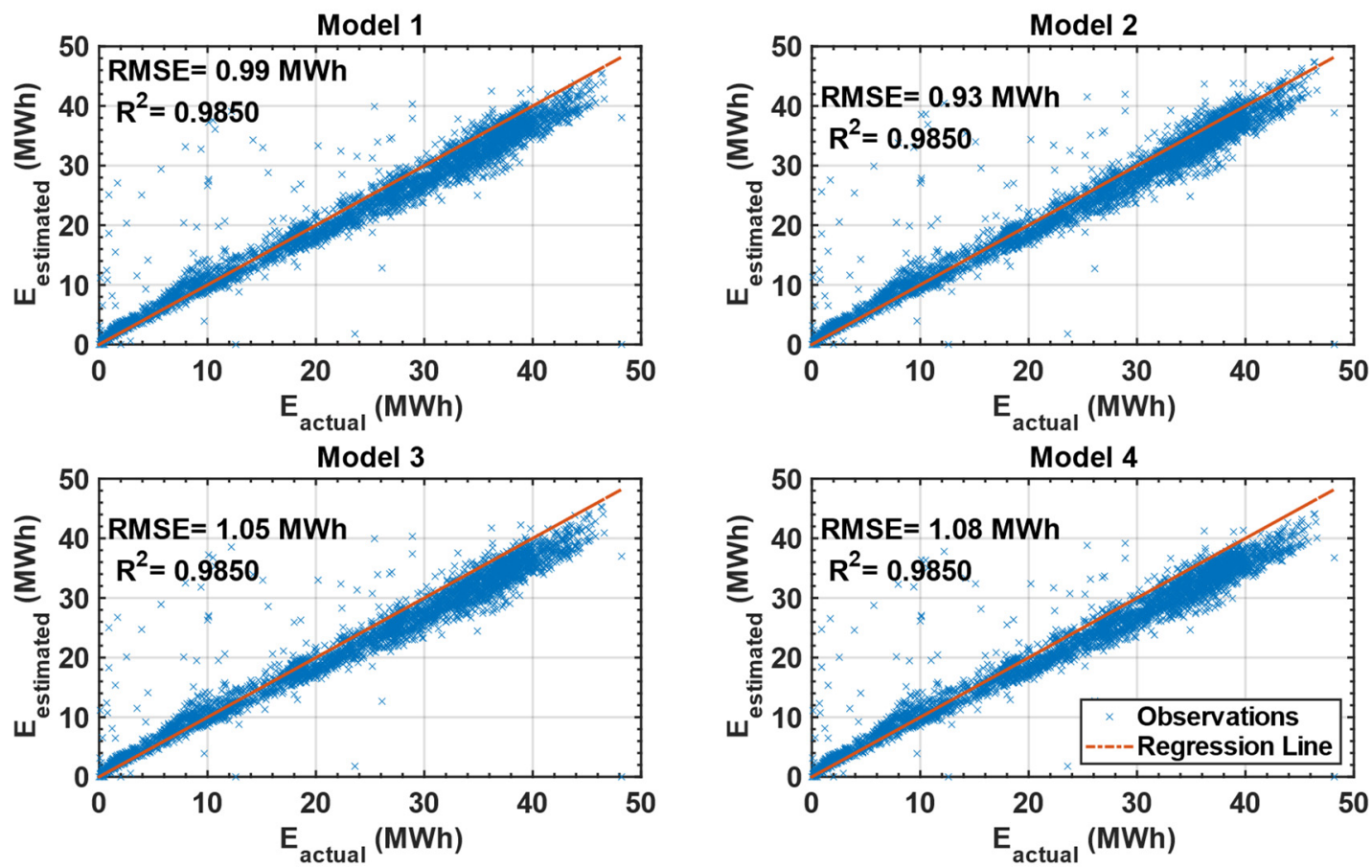

Figure 6. The goodness of fit of different energy estimation models of the fixed PV plant.
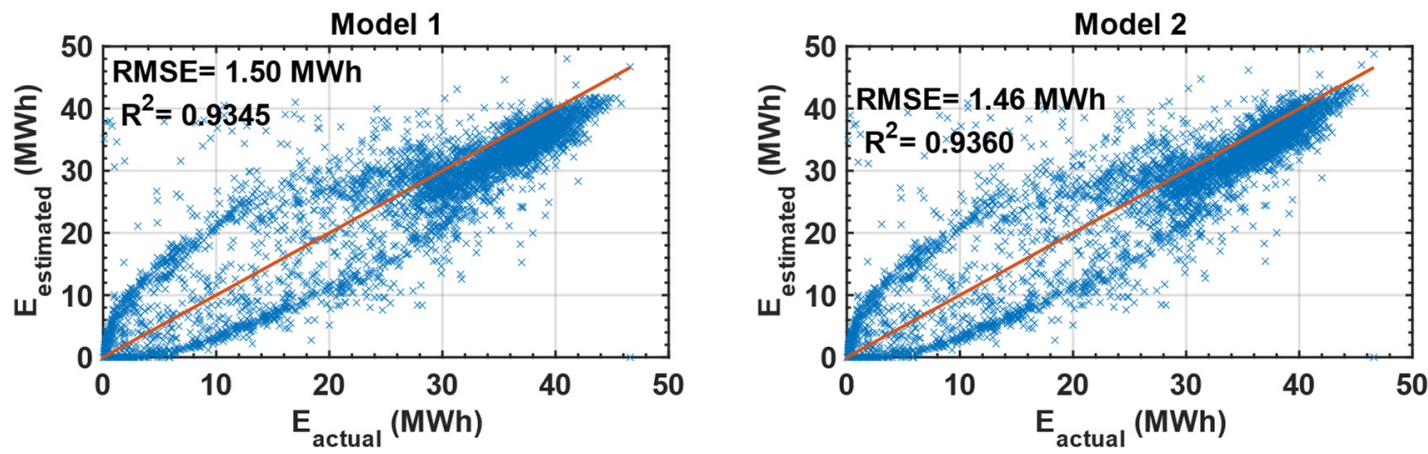

Model 3
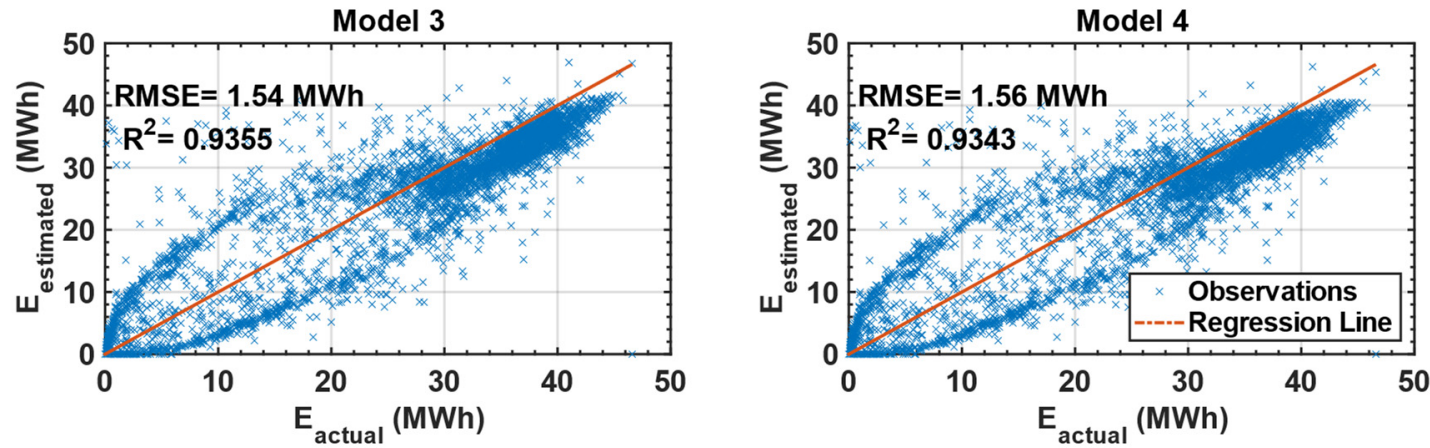

Figure 7. The goodness of fit of different energy estimation models of the tracked PV plant. 
The deviation between the measured and estimated energy prediction is expected, knowing that the empirical models (the models used to estimate the PV cell temperature) adopted in this study were obtained at specific locations with certain ambient conditions that deviate from those in this study. In addition, the dust $\backslash$ soiling accumulation amount and the drop in the PV performance due to this accumulation could be another source for the deviation. The lack of PV cell and dust accumulation measurements at the PV location prevents further improvement on the PV estimation models. Such measures could be used to find new empirical models for this location.

\subsection{Effect of Cleaning Frequency}

The effect of dust/soil accumulation on the PV can be significant if the cleaning frequency is insufficient, depending on the accumulation rates and ambient conditions. The location of the PV plant investigated in this study is characterized by an arid climate with rare rainfall events and a high probability of dust/soil accumulation. Hence, regular PV cleaning is vital for ensuring the PV plant's best performance and maximizing its profits. Figure 8 shows the effect of the cleaning period on the annual energy production and the $L C O E$ of the two PV sub-plants. It can be depicted from the figure, that irregular cleaning of the PV modules causes a significant drop in PV production and increases the $L C O E$. Moreover, it is evident in Figure 8 that decreasing cleaning frequency decreases the LCOE. However, this trend inverts after a cleaning frequency threshold of two weeks, implying that the best cleaning frequency that increases the energy production-and that corresponds to the lowest $L C O E$ - is two weeks. Therefore, a cleaning frequency of two weeks is suggested in the PV plant, instead of the current three months, to ensure the best performance and the lowest LCOE of the PV plant. Moreover, Figure 5 can be used to introduce empirical formulas for quantifying the effect of the cleaning frequency on the annual energy production and the LCOE in regions with similar environmental conditions, as shown in Table 7.
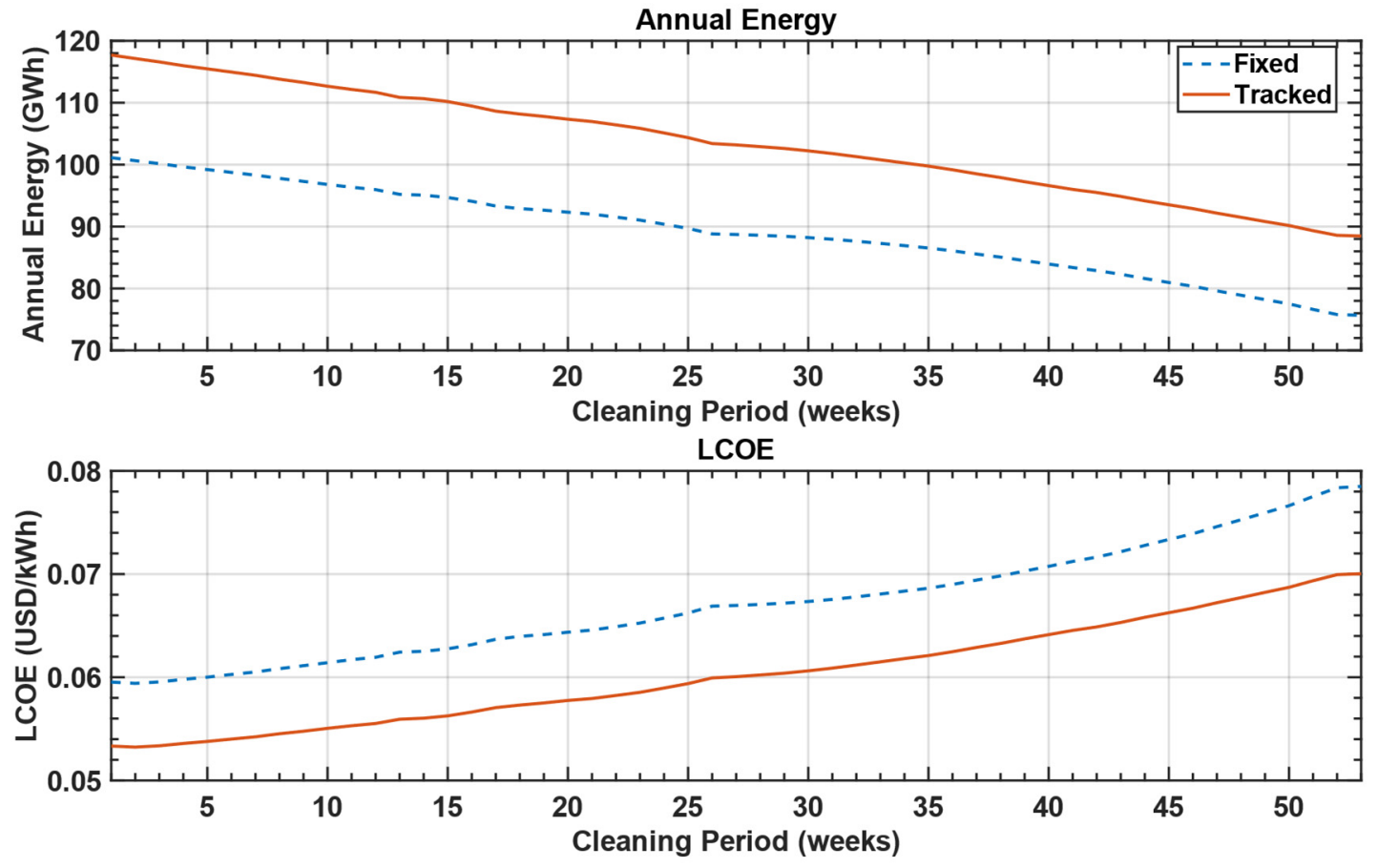

Figure 8. Effect of dust cleaning frequency on the annual energy production and the LCOE of the fixed and tracked PV plants. 
Table 7. Empirical formulas for estimating the annual energy production and the LCOE of PV power plants in desert conditions similar to the environmental conditions at the investigated plant.

\begin{tabular}{ccc}
\hline System Type & Annual Energy (MWh/MWp) & LCOE (USD/kWh) \\
\hline Fixed & $-4.49 \times \mathrm{f}_{\mathrm{cl}}+986.86$ & $3.482 \times 10^{-3} \times \mathrm{f}_{\mathrm{cl}}+0.0577$ \\
Tracked & $-5.36 \times \mathrm{f}_{\mathrm{cl}}+1149.22$ & $3.21 \times 10^{-3} \times \mathrm{f}_{\mathrm{cl}}+0.0517$ \\
\hline
\end{tabular}

To highlight the benefits of this change in the cleaning frequency, Table 8 shows a quantitative comparison between the estimated annual energy production and the LCOE of the two PV plants at the current and proposed cleaning frequencies. It can be depicted that the proposed cleaning frequency increases the annual energy production of the fixed and tracked PV plants by $4.88 \%$ and $4.89 \%$, respectively. This also can be noticed in the weekly energy profile of the two PV plants, as shown in Figure 9, at the two cleaning frequencies. It can be seen in Figure 9 that the tracked PV plant outperforms the fixed plant during the summer months (which is expected since the tracked PV panels follow the sun), and thus increases the beam radiation incident on the surface. However, in winter months both plants have almost the same energy production since the beam radiation in these months has less contribution than the other solar radiation components due to the cloud cover. Moreover, two weeks' cleaning frequency decreases the LCOE of the fixed and tracked PV plants by $4.04 \%$ and $4.14 \%$, respectively, as shown in Table 8 . Hence, this highlights the viability and significance of adopting the new cleaning frequency.

Table 8. The change in the annual energy production and the LCOE of the fixed and tracked PV plants with the proposed dust cleaning frequency.

\begin{tabular}{cccc}
\hline Type & Cleaning Freq. (Weeks) & Annual Energy (GWh) & LCOE (USD/kWh) \\
\hline \multirow{2}{*}{ Fixed } & 12 & 95.96 & 0.0619 \\
& 2 & 100.64 & 0.0594 \\
\hline \multirow{2}{*}{ Tracked } & 12 & 111.68 & 0.0555 \\
& 2 & 117.14 & 0.0532 \\
\hline
\end{tabular}
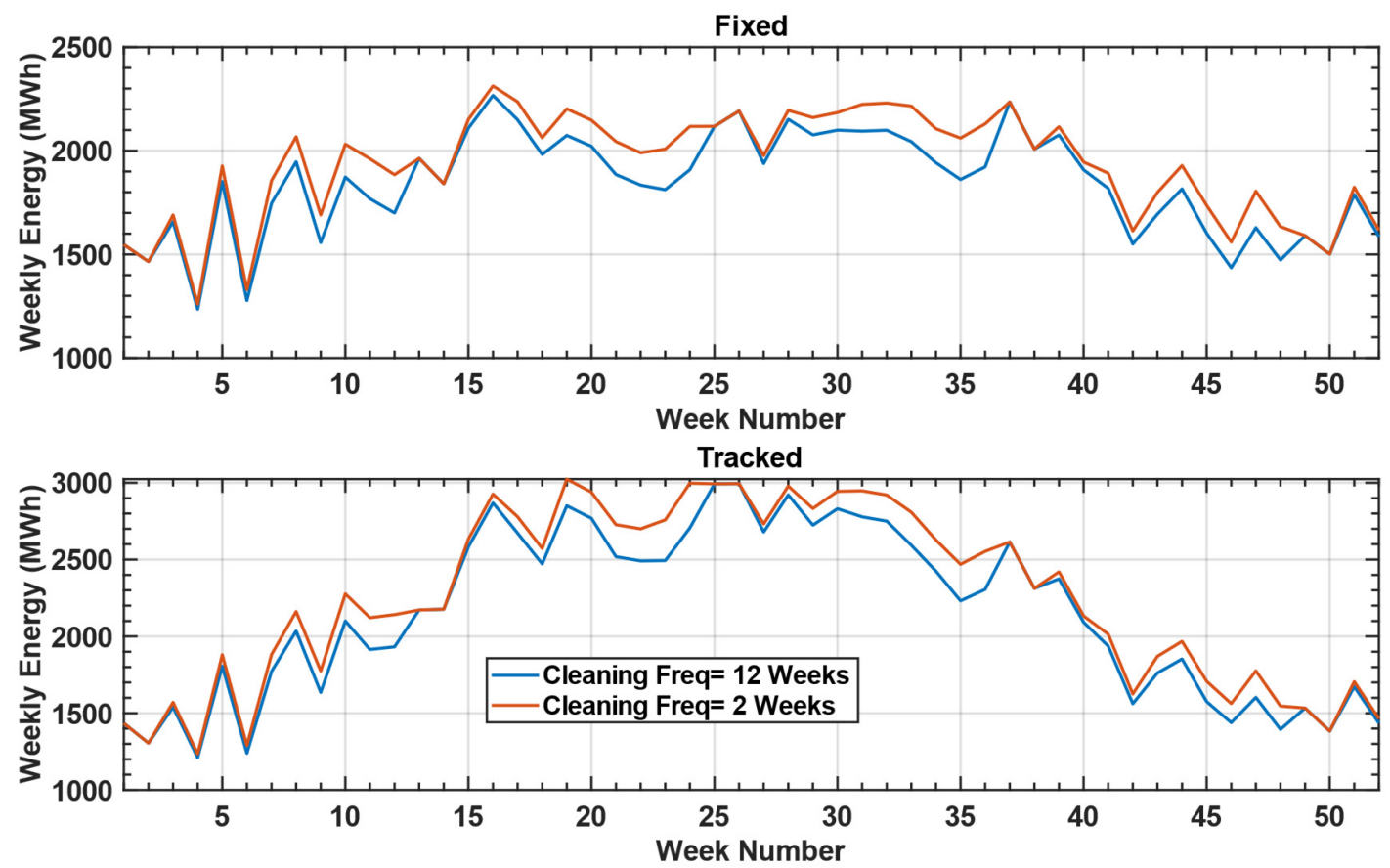

Figure 9. The total weekly energy production with the current and proposed cleaning frequency of the fixed and tracked PV plants. 


\section{Conclusions}

In this study, five PV energy estimation models were evaluated and compared to the actual energy produced from Jordan's largest PV power plants with a capacity of 103 MW. The plant consists of two sub-plants: a 51.7 MW fixed panels plant and a 51.7 MW single-axis tracking panels plant. Root mean square error (RMSE) and the coefficient of determination (R2) were used to assess the performance of the estimation models. Moreover, the effect of cleaning frequency on the annual energy production as well as the levelized cost of electricity ( $L C O E)$ of the PV plant was investigated. Finally, the 103 MW PV plant's best cleaning frequency was found that maximizes the annual energy production and minimizes the $L C O E$.

The investigated models in this study have very similar performance in predicting the energy production, with $\mathrm{R}^{2}$ varying between 0.93 and 0.98 , and RMSE between 0.93-1.56 MWh for both sub-plants. The results indicate that model 2 slightly outperforms the rest of the models-including the standard model-in terms of $\mathrm{R}^{2}$ and RMSE. The deviation between the measured and estimated energy prediction is expected for many reasons, such as:

- Local wind speeds on the PV modules, where the used empirical models were developed for fixed PV modules only.

- The adopted models do not incorporate the effect of wind direction due to the unavailability of wind direction measurements at the PV plant.

- The models adopted in this study were obtained at specific locations with certain ambient conditions that deviate from the ones in this study.

- Finally, the dust $\backslash$ soiling accumulation rates and the drop amount in the PV performance due to this accumulation could be another source for the deviation.

The plant is located in the southern part of Jordan, which is considered a desert with a very hot and dry climate. Hence, regular cleaning of PV modules is required to ensure maximum performance of the PV panels. It is concluded in this study that cleaning the panels every two weeks is recommended, instead of every three months, whereby the new cleaning frequency will increase the annual energy by almost $5 \%$ and decrease the LCOE by nearly $4 \%$ for the fixed and tracked panels.

Author Contributions: Conceptualization, L.A.-G. and M.A.S.; methodology, L.A.-G.; software, L.A.-G.; validation L.A.-G., M.A.S. and A.A.; formal analysis, L.A.-G., M.A.S. and A.A.; investigation, L.A.-G.; resources, L.A.-G. and M.A.S.; writing-original draft preparation, L.A.-G. and M.A.S.; writing-review and editing, L.A.-G., M.A.S. and A.A.; supervision, L.A.-G. and A.A.; project administration, L.A.-G. and A.A.; funding acquisition, A.A. All authors have read and agreed to the published version of the manuscript.

Funding: This research received no external funding.

Institutional Review Board Statement: Not applicable.

Informed Consent Statement: Not applicable.

Data Availability Statement: The data supporting reported results are available in the manuscript.

Acknowledgments: The authors would like to thank the Estonian Centre of Excellence in Zero Energy and Resource Efficient Smart Buildings and Districts, ZEBE, grant TK146, funded by the European Regional Development Fund to support this research.

Conflicts of Interest: The authors declare no conflict of interest.

\section{Nomenclature}

$\begin{array}{ll}A_{m} & \text { PV module area, } \mathrm{m}^{2} ; \\ \alpha_{1} & \text { Faiman wind cooling coefficient, } \mathrm{W} \mathrm{s} /{ }^{\circ} \mathrm{C} \mathrm{m}^{3} ; \\ \alpha_{0} & \text { Faiman radiation heating coefficient, } \mathrm{W} /{ }^{\circ} \mathrm{C} \mathrm{m}^{2} ; \\ C_{P V} & \text { PV capital cost, USD; }\end{array}$




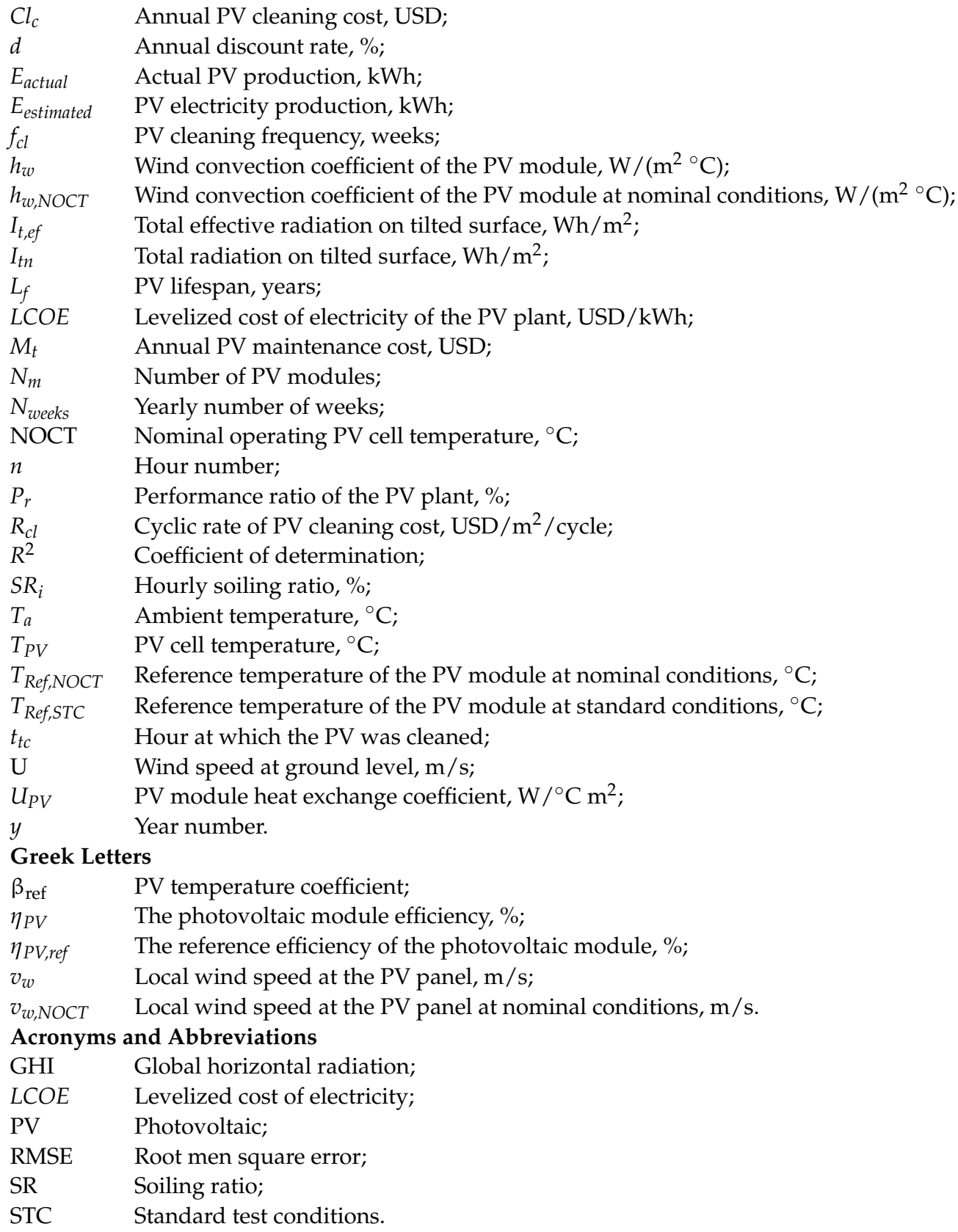

\section{References}

1. Al-Ghussain, L.; Abubaker, A.M.; Ahmad, A.D. Superposition of Renewable-Energy Supply from Multiple Sites Maximizes Demand-Matching: Towards 100\% Renewable Grids in 2050. Appl. Energy 2021, 284, 116402. [CrossRef]

2. Al-Ghussain, L.; Al-Oran, O.; Lezsovits, F. Statistical Estimation of Hourly Diffuse Radiation Intensity of Budapest City. Environ. Prog. Sustain. Energy 2021, 40, e13464. [CrossRef]

3. Al-Ghussain, L. Global warming: Review on driving forces and mitigation. Environ. Prog. Sustain. Energy 2018, 38, 13-21. [CrossRef]

4. The Paris Agreement / United Nations. Available online: https://www.un.org/en/climatechange/paris-agreement (accessed on 28 September 2021).

5. Al Siyabi, I.; Al Mayasi, A.; Al Shukaili, A.; Khanna, S. Effect of Soiling on Solar Photovoltaic Performance under Desert Climatic Conditions. Energies 2021, 14, 659. [CrossRef]

6. Anagreh, Y.; Bataineh, A. Renewable energy potential assessment in Jordan. Renew. Sustain. Energy Rev. 2011, 15, 2232-2239. [CrossRef]

7. AL-Ghussain, L.; Taylan, O.; Fahrioglu, M. Sizing of a Photovoltaic-Wind-Oil Shale Hybrid System: Case Analysis in Jordan. J. Sol. Energy Eng. 2018, 140, 1-12. [CrossRef]

8. Alsaad, M.A. Wind energy potential in selected areas in Jordan. Energy Convers. Manag. 2013, 65, 704-708. [CrossRef] 
9. National Electric Power Company. NEPCO Annual Report. 2020. Available online: https://www.nepco.com.jo/annual_report_ ar.aspx (accessed on 28 September 2021).

10. Jordan 2020-2030 Energy Strategy-The Leading Solar Magazine in India. Available online: https:/ / www.eqmagpro.com/jordan2020-2030-energy-strategy / (accessed on 29 September 2021).

11. Al-Ghussain, L. Economic Assessment of PV Investments in Jordan. Innov. Energy Res. 2017, 6, 159. [CrossRef]

12. Hrayshat, E.S. Analysis of renewable energy situation in Jordan. Renew. Sustain. Energy Rev. 2007, 11, 1873-1887. [CrossRef]

13. Al-omary, M.; Kaltschmitt, M.; Becker, C. Electricity system in Jordan: Status \& prospects. Renew. Sustain. Energy Rev. 2018, 81, 2398-2409. [CrossRef]

14. Al-Ghussain, L.; Ahmad, A.D.; Abubaker, A.M.; Abujubbeh, M.; Almalaq, A.; Mohamed, M.A. A Demand-Supply MatchingBased Approach for Mapping Renewable Resources towards 100\% Renewable Grids in 2050. IEEE Access 2021, 9, 58634-58651. [CrossRef]

15. Suman; Sharma, P.; Goyal, P. Analysing the effects of solar insolation and temperature on PV cell characteristics. Mater. Today Proc. 2021, 45, 5539-5543. [CrossRef]

16. Hammad, B.; Al-Abed, M.; Al-Ghandoor, A.; Al-Sardeah, A.; Al-Bashir, A. Modeling and analysis of dust and temperature effects on photovoltaic systems' performance and optimal cleaning frequency: Jordan case study. Renew. Sustain. Energy Rev. 2018, 82, 2218-2234. [CrossRef]

17. Al-Ghussain, L.; Ahmed, H.; Haneef, F. Optimization of hybrid PV-wind system: Case study Al-Tafilah cement factory, Jordan. Sustain. Energy Technol. Assess. 2018, 30, 24-36. [CrossRef]

18. Schwingshackl, C.; Petitta, M.; Wagner, J.E.; Belluardo, G.; Moser, D.; Castelli, M.; Zebisch, M.; Tetzlaff, A. Wind Effect on PV Module Temperature: Analysis of Different Techniques for an Accurate Estimation. Energy Procedia 2013, 40, 77-86. [CrossRef]

19. Skoplaki, E.; Boudouvis, A.G.; Palyvos, J.A. A simple correlation for the operating temperature of photovoltaic modules of arbitrary mounting. Sol. Energy Mater. Sol. Cells 2008, 92, 1393-1402. [CrossRef]

20. Kurtz, S.; Mier, D.; Kempe, M.; Bosco, N.; Whitefield, K.; Wohlgemuth, J.; Dhere, N.; Zgonena, T. Evaluation of high-temperature exposure of rack-mounted photovoltaic moduless. In Proceedings of the 2009 34th IEEE Photovoltaic Specialists Conference (PVSC), Philadelphia, PA, USA, 7-12 June 2009; pp. 002399-002404. [CrossRef]

21. Koehl, M.; Heck, M.; Wiesmeier, S.; Wirth, J. Modeling of the nominal operating cell temperature based on outdoor weathering Sol. Energy Mater. Sol. Cells 2011, 95, 1638-1646. [CrossRef]

22. Mattei, M.; Notton, G.; Cristofari, C.; Muselli, M.; Poggi, P. Calculation of the polycrystalline PV module temperature using a simple method of energy balance. Renew. Energy 2006, 31, 553-567. [CrossRef]

23. Njok, A.O.; Ogbulezie, J.C. The Effect of Relative Humidity and Temperature on Polycrystalline Solar Panels Installed Close to a River. Phys. Sci. Int. J. 2019, 20, 1-11. [CrossRef]

24. Guo, B.; Javed, W.; Figgis, B.W.; Mirza, T. Effect of dust and weather conditions on photovoltaic performance in Doha, Qatar. In Proceedings of the 2015 First Workshop on Smart Grid and Renewable Energy (SGRE), Doha, Qatar, 22-23 March 2015. [CrossRef]

25. Ahmed, M.; Al-Khawaldeh, H.; Alkhawaldeh, L.; Al-Tarawneh, A. The Effect of Soiling and Periodic Cleaning on the Performance of Solar Power Plants in Ma'an, Jordan. Innov. Syst. Des. Eng. 2018, 9, 14-18.

26. Gökmen, N.; Hu, W.; Hou, P.; Chen, Z.; Sera, D.; Spataru, S. Investigation of wind speed cooling effect on PV panels in windy locations. Renew. Energy 2016, 90, 283-290. [CrossRef]

27. Vasel, A.; Iakovidis, F. The effect of wind direction on the performance of solar PV plants. Energy Convers. Manag. 2017, 153, 455-461. [CrossRef]

28. Meral, M.E.; Dinçer, F. A review of the factors affecting operation and efficiency of photovoltaic based electricity generation systems. Renew. Sustain. Energy Rev. 2011, 15, 2176-2184. [CrossRef]

29. Figgis, B.; Ennaoui, A.; Ahzi, S.; Rémond, Y. Review of PV soiling particle mechanics in desert environments. Renew. Sustain. Energy Rev. 2017, 76, 872-881. [CrossRef]

30. Zaihidee, F.M.; Mekhilef, S.; Seyedmahmoudian, M.; Horan, B. Dust as an unalterable deteriorative factor affecting PV panel's efficiency: Why and how. Renew. Sustain. Energy Rev. 2016, 65, 1267-1278. [CrossRef]

31. Ullah, A.; Imran, H.; Maqsood, Z.; Butt, N.Z. Investigation of optimal tilt angles and effects of soiling on PV energy production in Pakistan. Renew. Energy 2019, 139, 830-843. [CrossRef]

32. Shah, A.H.; Hassan, A.; Laghari, M.S.; Alraeesi, A. The Influence of Cleaning Frequency of Photovoltaic Modules on Power Losses in the Desert Climate. Sustainability 2020, 12, 9750. [CrossRef]

33. Hajjaj, C.; Merrouni, A.A.; Bouaichi, A.; Benhmida, M.; Sahnoun, S.; Ghennioui, A.; Zitouni, H. Evaluation, comparison and experimental validation of different PV power prediction models under semi-arid climate. Energy Convers. Manag. 2018, 173, 476-488. [CrossRef]

34. Fathi, M.; Abderrezek, M.; Grana, P. Technical and economic assessment of cleaning protocol for photovoltaic power plants: Case of Algerian Sahara sites. Sol. Energy 2017, 147, 358-367. [CrossRef]

35. Sreenath, S.; Sudhakar, K.; Yusop, A.F.; Solomin, E.; Kirpichnikova, I.M. Solar PV energy system in Malaysian airport: Glare analysis, general design and performance assessment. Energy Reports 2020, 6, 698-712. [CrossRef]

36. Martín-Martínez, S.; Cañas-Carretón, M.; Honrubia-Escribano, A.; Gómez-Lázaro, E. Performance evaluation of large solar photovoltaic power plants in Spain. Energy Convers. Manag. 2019, 183, 515-528. [CrossRef] 
37. Sundaram, S.; Babu, J.S.C. Performance evaluation and validation of 5 MWp grid connected solar photovoltaic plant in South India. Energy Convers. Manag. 2015, 100, 429-439. [CrossRef]

38. Kumar, B.S.; Sudhakar, K. Performance evaluation of 10 MW grid connected solar photovoltaic power plant in India. Energy Rep. 2015, 1, 184-192. [CrossRef]

39. Loveday, D.L.; Taki, A.H. Convective heat transfer coefficients at a plane surface on a full-scale building façade. Int. J. Heat Mass Transf. 1996, 39, 1729-1742. [CrossRef]

40. Louy, M.; Tareq, S.; Al-Jufout, Q.; Alsafasfeh, Q.; Wang, C. Effect of dust on the 1-MW photovoltaic power plant at Tafila Technical University. In Proceedings of the 2017 8th International Renewable Energy Congress (IREC), Amman, Jordan, 21-23 March 2017. [CrossRef]

41. Nepal, P.; Korevaar, M.; Ziar, H.; Isabella, O.; Zeman, M. Accurate Soiling Ratio Determination with Incident Angle Modifier for PV Modules. IEEE J. Photovolt. 2019, 9, 295-301. [CrossRef]

42. Al-Ghussain, L.; Taylan, O. Sizing methodology of a PV/wind hybrid system: Case study in cyprus. Environ. Prog. Sustain. Energy 2019, 38, e13052. [CrossRef]

43. Al-Ghussain, L.; Abujubbeh, M.; Fahrioglu, M. Assessment of PV Investments in Northern Cyprus. In Proceedings of the 16th International Conference on Clean Energy (ICCE-2018), Famagusta, Cyprus, 9-11 May 2018.

44. Feldman, D.; Ramasamy, V.; Fu, R.; Ramdas, A.; Desai, J.; Margois, R.U.S. Solar Photovoltaic System and Energy Storage Cost Benchmark: Q1 2020. Available online: https:/ / www.nrel.gov/docs/fy22osti/80694.pdf (accessed on 28 September 2021).

45. Rad, M.A.V.; Toopshekan, A.; Rahdan, P.; Kasaeian, A.; Mahian, O. A comprehensive study of techno-economic and environmental features of different solar tracking systems for residential photovoltaic installations. Renew. Sustain. Energy Rev. 2020, $129,109923$. [CrossRef]

46. Al-Ghussain, L.; Abujubbeh, M.; Ahmad, A.D.; Abubaker, A.M.; Taylan, O. 100 \% Renewable Energy Grid for Rural Electrification of Remote Areas: A Case Study in Jordan. Energies 2020, 13, 4908. [CrossRef] 